\title{
Fiestas, rituales y nuevas TIC. Usos políticos y religiosos del Internet y el celular en la Comunidad de Yanque (Caylloma, Arequipa)
}

\author{
Mario Sánchez Dávila \\ mario.sanchez.davila@gmail.com \\ Pontificia Universidad Católica del Perú
}

\section{RESUMEN:}

Este artículo se propone comprender, a través de un enfoque cualitativo y etnográfico, los usos políticos y religiosos de las nuevas tecnologías de información y comunicación (o nuevas TIC) en la comunidad de Yanque (Caylloma, Arequipa, Perú), encontrando que el Internet y el celular, lejos de desintegrar la comunidad, son utilizados como un medio para preservar las tradiciones de su cultura local, pero también son usados como una herramienta para reforzar el estatus y el prestigio de los grupos de poder, y, por ello, para reafirmar las jerarquías y desigualdades dentro del campo social estratificado de Yanque.

Palabras Clave: Fiestas; Rituales; Nuevas TIC; Andes; Yanque.

\section{Festivities, rituals and new Ict's. Political and religious uses of Internet and cell phone in the community of Yanque (Caylloma, Arequipa)}

\begin{abstract}
:
This paper intends to understand, through a qualitative and ethnographic approach, the political and religious uses of the new information and communication technologies (or new ICTs) in the community of Yanque (Caylloma, Arequipa, Peru), finding that the Internet and cell phone, far from disintegrating the community, are used as means to preserve the traditions of their local culture, but they are also used as tools to reinforce the status and prestige of the power groups, and, therefore, to reaffirm the hierarchies and inequalities within the stratified social field of Yanque.

Keywords: Festivities; Rituals; New ICT's; Andes; Yanque.
\end{abstract}

(C) Los autores. Este artículo es publicado por ISHRA, Revista del Instituto Seminario de Historia Rural Andina de la Facultad de Ciencias Sociales de la Universidad Nacional Mayor de San Marcos. Este es un artículo de acceso abierto, distribuido bajo los términos de la licencia Creative Commons Atribucion - No Comercia Compartir Igual 4.0 Internacional. (http://creativecommons.org/licenses/by-nc-sa/4.0/) que permite el uso no comercial, distribución y reproducción en cualquier medio, siempre que la obra original sea debidamente citada. 


\section{Introducción}

El presente artículo se propone comprender los usos políticos y religiosos de las nuevas tecnologías de información y comunicación (nuevas TIC) al interior de la comunidad de Yanque en el valle del Colca (Caylloma, Arequipa). A partir de un reciente balance bibliográfico (Sánchez Dávila, 2016) señalamos que dicho objetivo es necesario por dos razones: 1) En la actualidad, existen pocos estudios sobre las nuevas TIC en los Andes peruanos y 2) Estos estudios se han centrado básicamente en las dimensiones sociales de la expresión identitaria, el desarrollo productivo y la educación oficial, desplazando el interés por otras dimensiones de un contexto socio-cultural mucho más amplio, dinámico e interconectado, como la interrelación entre las nuevas TIC y las dimensiones políticas y religiosas $-\mathrm{y}$, con ellas, también el funcionamiento social de prácticas mitológicas, rituales, festivas, laborales, mercantiles o estatales- en un escenario andino lleno de acuerdos y de tensiones individuales y colectivas.

Así, los usos del Internet y del celular en la dimensión política y religiosa (en los contextos festivos y rituales) nos han permitido apreciar de una manera clara y precisa cómo los yanqueños usan las nuevas TIC para reafirmar su cultura con el objetivo de adaptarse y/o de mantenerse en diversos escenarios sociales. Los yanqueños realizan una apropiación local del Internet y el celular, asimilando estos instrumentos extranjeros a sus propias tradiciones regionales, y usándolos para sus propias necesidades sociales (Romero, 2001). Y es que las nuevas TIC, lejos de desintegrar lo cultural, son utilizadas como medio para revitalizar lo que los yanqueños consideran es la parte tradicional de su cultura, tanto afuera como adentro del pueblo. No obstante, al preservar tradiciones de su cultura local para adaptarse a escenarios económicos (como la agricultura y el turismo) y para mantenerse en escenarios políticos y religiosos, se preservan también, tal y como veremos, las inequidades y jerarquías sociales ya existentes en el pueblo.

Este artículo se encuentra divido en tres partes: la primera sección contextualiza la dimensión político-religiosa de la comunidad de Yanque en el marco de las fiestas y los rituales; la segunda sección describe y analiza los datos etnográficos sobre los usos políticos y religiosos de las nuevas TIC; $y$, la tercera sección elabora balances, comparaciones y aportes como conclusiones del estudio.

\section{Fiestas y rituales en la comunidad de Yanque}

La comunidad (a 3,417 msnm.) es uno de los dieciséis distritos que conforman la provincia de Caylloma, cuya capital actual es el distrito de Chivay dentro del valle del Colca, en el departamento de Arequipa. Yanque se encuentra ubicado a $150 \mathrm{~km}$ al noreste de la ciudad de Arequipa, a tres horas de camino en automóvil, por medio de una carretera asfaltada. El pueblo se inserta geográficamente dentro del valle del Colca y tiene como límites geográficos a las comunidades de Ichupampa, Coporaque, Achoma y Chivay. A diferencia de las otras comunidades, Yanque ha ocupado, históricamente, una privilegiada y estratégica posición política y económica dentro del valle del Colca (Sánchez Dávila, 2017a). En primer lugar, como sede central del poder del señorío Collagua que controlaba la parte norte, este y sureste del valle, desde los siglos X al XV. En segundo lugar, como centro de administración del Tahuantinsuyu inca, en el valle, desde los siglos XV al XVI. En tercer lugar, como capital de corregimiento y repartimiento del virreinato español, desde los siglos XVI al XVIII. En cuarto lugar, como capital de la provincia de Caylloma desde mediados del siglo XIX hasta las primeras décadas del siglo XX. Y, en quinto lugar, como espacio turístico donde se concentra la mayor cantidad de hoteles de todo el valle, desde finales del siglo XX hasta la actualidad. 
A pesar de que existe una propiedad privada de la tierra y el ganado, y de que la organización interna de Yanque se encuentre jerarquizada y pueda favorecer a unos más que a otros, las necesidades de cooperación superan el marco de la unidad doméstica; por ejemplo, en la limpieza de canales, en la construcción de reservorios, en el levantamiento de cercos para el aprovechamiento de pastos, en la construcción y mantenimiento de caminos, en el barbecho de los terrenos, en la construcción de andenes y de casas, o en la esquila del ganado lanar (Golte, 1987; De la Cadena, 1989).

En Yanque, la organización comunal tiene una importancia central para las unidades familiares dentro de un territorio geográfico, económico y político colectivo. Por ello, de acuerdo con Plaza y Francke (1981), la dimensión comunal brinda a la dimensión familiar no solo una serie de condiciones y posibilidades para que desarrollen su producción, sino que también controla las formas y los límites dentro de los cuales la producción familiar puede realizarse; así, pues, la familia constituye la unidad de producción campesina, pero es la comunidad la que organiza el control de los recursos tanto naturales (tierra y agua) como sociales (el uso colectivo de la fuerza de trabajo para el bien común), porque la organización colectiva de la comunidad campesina (la esfera de producción supradoméstica, siguiendo a Guillet, 1978) es aún necesaria en la dimensión productiva de las unidades domésticas, incluso cuando se encuentra ya inserta en una economía capitalista (Kervyn, 1989; Fonseca y Mayer, 1988; Gonzales de Olarte, 1987 y 1982; Figueroa, 1983; Montoya, 1979).

Una de las más visibles y cohesionadas manifestaciones de estas necesidades de cooperación colectiva son los trabajos festivos o las fiestas laborales, porque existe una íntima relación entre la producción (trabajo) y la celebración (fiesta) en las actividades productivas colectivas vigentes en el mundo andino desde las sociedades prehispánicas hasta las comunidades de los Andes contemporáneos (Ráez, 2008, 2002, 2001 y 1998; Gelles, 2002; Treacy, 1994; Ossio, 1992; Valderrama y Escalante, 1986). Actualmente, existen tres actividades colectivas económicas que involucran labores, fiestas y rituales: la agricultura (en épocas de siembra y cosecha), la ganadería (en tiempos de herranza, esquila y rodeo) y la construcción (en periodos de levantamiento de viviendas, locales comunales, caminos y puentes, y de limpieza y refacción de canales de regadío y de reservorios del sistema hidráulico).

No obstante, entre los siglos XVI y XX, acontecieron profundas transformaciones que han reestructurado la importancia contemporánea de los trabajos festivos o fiestas laborales como mecanismos culturales de ordenamiento social de los miembros de las comunidades andinas. Según Ráez (2008), entre los siglos XVI-XVIII, se privatizó el recurso productivo (las tierras agropecuarias), el territorio (las reducciones de indios) y la riqueza del trabajo (productos agropecuarios); y entre los siglos XIX-XX, se privatizaron los bienes y recursos comunales a favor del gamonalismo; se modernizaron las relaciones de producción, tanto por los ciclos expansivos de la economía peruana (la exportación del guano, el salitre, la lana, y la emergencia de economías globales) como por la mecanización agrícola y proletarización campesina, que debilitaron la oferta de mano de obra laboral, las redes de parentesco, la reciprocidad andina y la protección colectiva de las tierras, el territorio y las riquezas; $y$, finalmente, aparecieron discursos en contra de las expresiones de lo andino que produjeron desarraigo étnico y desorganización de la producción (a fines de los años ochenta del siglo XX, Sendero Luminoso al prohibir toda expresión ajena a la política del partido; y las iglesias evangelistas y escatológicas, luego de la época de violencia armada interna, prohibieron toda expresión de religiosidad popular católica o quechua). 
Es por ello que, a pesar de esas radicales transformaciones en las dimensiones económicas en los Andes a través de los siglos, y de que en algunas comunidades ya no se realicen rituales ni fiestas, aunque sí perdure el trabajo colectivo, es necesario preguntar ¿qué permite la persistencia de labores, fiestas y rituales, como prácticas colectivas, en el mundo andino peruano? Plaza y Francke (1981) y Ráez (2008) ofrecen, respectivamente, una respuesta a esta pregunta.

Plaza y Francke (1981) afirman que la organización colectiva tiene tres funciones motoras: 1) Identidad, que hace que sus miembros se reconozcan como pertenecientes a un grupo común, cohesionados socialmente por su historia cultural compartida. 2) Representación, para velar, hacia fuera, desde una organización suprafamiliar, como potencializador de las fuerzas individuales de las familias. 3) Defensa, frente a extraños, tanto de sus recursos como de su forma de organizarse y gobernarse. Asimismo, señalan que las labores, fiestas y rituales reafirman el respeto colectivo a las tradiciones al reproducirse una estructura de cargos jerárquicos, rotativos y legitimados socialmente al interior de la comunidad.

Ráez (2008) señala tres motivos primordiales para explicar la persistencia de las prácticas colectivas: 1) Porque permiten recrear identidades que refuerzan la pertenencia de todos los individuos a la colectividad. 2) Porque permiten construir espacios de defensa política y estrategias para garantizar la defensa de los derechos comunales. 3) Porque permiten la movilización y manejo de mano de obra y del conocimiento tradicional sobre el entorno, pues resulta más rentable que la organización comunitaria maneje recursos naturales de subsistencia colectiva (tierra y agua) a que estos mismos sean privatizados en relaciones contractuales, agudizando las ya existentes diferencias internas económico-políticas. Así, allí donde persisten los trabajos festivos ritualizados es porque, aunque la propiedad sea privada, las comunidades todavía mantienen la protección colectiva de los bienes y los recursos productivos así como una fuerte organización política que determina formas de acceso a dichos recursos y a la movilización de la mano de obra laboral; y allí donde las comunidades han perdido el control colectivo de sus recursos (en detrimento de procesos de privatización), menos posibilidades tienen de organizar las fiestas laborales ritualizadas y se circunscriben solo al trabajo asalariado o a la renta del bien.

Benavides (1987) señaló que muchas ceremonias colectivas en Yanque se pueden dividir entre aquellas que se encuentran ligadas al trabajo obligatorio y aquellas ligadas al calendario litúrgico católico. En esa línea, Ráez (1998 y 2002) sugirió que los principales eventos del calendario social de las comunidades del Valle del Colca obedecen a una cuatripartición del tiempo anual que se encuentra directamente relacionada con dimensiones agrícolas y ganaderas. Y, por ello, la existencia de cuatro tiempos festivos: 1). El tiempo de escasez (los meses de agosto a diciembre asociados a la precariedad de cosechas y pastos, a la preparación de tierras de sembrío, a la limpieza de los canales de regadío y a los rituales propiciatorios); 2). El tiempo de protección (los meses de diciembre a febrero asociados a la lluvia, a la fecundidad agrícola y ganadera, al reconocimiento público de las nuevas autoridades y a los rituales de protección); 3). El tiempo de silencio (los meses de marzo a abril asociados a la Cuaresma y a la liturgia de la penitencia); y 4). El tiempo de agradecimiento (los meses de mayo a julio asociados a la cosecha, a los rituales de reciprocidad entre lo profano y lo sagrado, y a la reafirmación de lazos de parentesco social).

Rescatando las propuestas de estos estudios, y partiendo de las observaciones, entrevistas y conversaciones de nuestro trabajo de campo, es posible afirmar que, en la actualidad, ello sigue prevaleciendo en la comunidad, pues el calendario social de Yanque comprende tanto eventos relacionados a la producción (actividades laborales y rituales vinculadas a la actividad agrícola y ganadera) como eventos relacionados a la celebración (fiestas a santos católicos coloniales y divinidades quechuas indígenas), en tanto prácticas colectivas que cohesionan a la comunidad a 
lo largo del año. Así, el calendario social yanqueño muestra la persistencia de una comunidad que 1) Se organiza colectivamente en torno al agua y la tierra, hecho visible no solo en sus eventos productivos, sino también en la marcación anual de su tiempo laboral-ritual (época de lluvia, época de helada, época de cosecha y época de siembra); la vigencia de una comunidad que 2) Se organiza colectivamente en torno al sincretismo de lo católico y lo quechua como parte de un mismo sistema religioso andino.

En Yanque, el quechua no tiene presencia en dimensiones tan visibles hacia afuera de la comunidad; pero, al interior de la misma, el quechua permanece vivo en la interacción de una serie de contextos sociales (como la producción y ritualización de la agricultura) y actores sociales (como los adultos y adultos mayores) más tradicionales. Este uso del quechua por parte de los adultos y adultos mayores es ubicable en contextos productivos, como la agricultura, donde a pesar de que ambos interlocutores puedan ser bilingües, se comunican en quechua porque «saben más cosas en quechua que en español sobre el campo». Pero sobre todo es posible ubicar el uso del quechua en contextos rituales cuando se trata de realizar pagos rituales al agua, a la tierra y a la montaña, las divinidades quechuas por excelencia en las comunidades andinas.

El trabajo (las faenas), la fiesta (la comida, la bebida y el baile) y el ritual (las ofrendas) son socialmente visibles durante los meses de febrero y agosto. Es en estos meses cuando se hacen los pagos rituales a las divinidades quechuas. Y es que, tanto en febrero como en agosto, según los yanqueños, la tierra está viva, caliente y fértil (una evidente metáfora reproductiva, una analogía entre naturaleza y biología: donde la tierra viva, caliente y fértil representa al útero ovulando, $\mathrm{y}$, por lo tanto, se revela también la importancia del agua como objeto seminal fecundador masculino). Pero en estos meses no solo se realizan los pagos sagrados al agua, la tierra y las montañas con la Iranta (sebo de alpaca o llama, maíz, incienso, pepas y lafras u hojas enteras de coca, y cunuja, una planta resinosa con fuerte olor, y otros elementos rituales), sino también se realiza el tinkachi de los animales, donde se ofrenda a la Mama Pacha y se lleva la contabilidad y marcación del ganado. Por ejemplo, días luego del Yarqa Aspiy de agosto del 2015, encontramos al Kamachikuq Yana haciendo, en su casa, la tinka de animales, con varias illas o representaciones de chacras y ganados en material de alabastro. En febrero, época de lluvia y de carnavales, es cuando se realizan las danzas del carnaval o puqllay de Yanque como celebración a la fertilidad con abundante chicha y comida. En agosto, si bien es un tiempo pasivo para la producción agrícola (siembra y cosecha), es un tiempo activo para la festividad y ritualización de esta actividad. Finalmente, recordemos que los eventos del año más concurridos son aquellos que tienen directa injerencia en la actividad agrícola de Yanque (Sánchez Dávila, 2017b y 2017c).

\section{III.Usos políticos y religiosos de las nuevas TIC: apuntes etnográficos}

Analizaremos, a continuación, el Yarqa Aspiy (del 01 al 04 de agosto), el Varamaya (01 de enero), el Tinkachi (tercer domingo de febrero) y el Puqllay (última semana de febrero). Estas fiestas y rituales porque son las ceremonias más importantes de la comunidad, convocando a una gran cantidad de yanqueños y símbolos colectivos que cohesionan a Yanque durante el tiempo y el espacio de su realización. Vale rescatar que estas fiestas y rituales contemporáneos vistos localmente como «tradicionales» o «ancestrales» son relativamente modernos en cuanto a su origen se refiere, ya que muchos no datan de antes del reciente siglo XX.

Lo tradicional no se encuentra en oposición con lo moderno, pues lo tradicional se encuentra vinculado a la tenaz conservación de muchas costumbres colectivas, y lo moderno se encuentra vinculado a la integración de la comunidad a circuitos mercantiles y comerciales (Diez, 2001a). 
Es por eso que las líneas límites entre lo tradicional y lo moderno se evaporan, pues ambas pueden, de hecho, coexistir y mezclarse en una variedad de formas y significados, donde lo global, lo cosmopolita y lo internacional no son elementos externos a muchas áreas de la vida social local en los Andes peruanos, ni implican la desaparición de las diferencias de las culturas locales insertas en un sistema global (Romero, 2004). Es precisamente una visión romántica la que muchas veces ha «(...) esencializado al indio y al mestizo andino sobre la base de patrones rígidos, fijos y tradicionales, segregados de las tendencias globales que ha afectado al resto del mundo, como si todas las comunidades en los Andes peruanos se hubieran mantenido aisladas de la modernidad y protegidas de la cultura de los medios de comunicación de masas, recluidas en sus propios espacios corporativos indios» (ibídem: 205). Precisamente por eso no estamos asumiendo -ingenuamente- que la modernidad llega recién a los tradicionales Andes peruanos en el siglo XXI, pues ello sería reforzar la idea de sentido común que sostiene -erróneamente- que las sociedades andinas son entidades aisladas (donde no existen relaciones con escenarios culturales exógenos), homogéneas (donde no existen estratificaciones ni jerarquías sociales) y estáticas (donde no existen procesos ni cambios a través de su historia). Por el contrario, reafirmamos la idea histórico-antropológica que las sociedades que existieron y existen actualmente en el territorio que hoy se comprende como el mundo andino (y la comunidad de Yanque en el Valle del Colca no es una excepción) experimentaron, antes y después del imperio incaico y de la colonización española, un proceso de interrelación de larga data y, por ello, transformaciones que fueron redefiniendo, periódicamente, sus escenarios socio-culturales a lo largo de su historia hasta el presente.

Pero, en vez de usar las categorías de tradición y modernidad, convenimos en que es mejor utilizar las categorías de continuidades y cambios. Porque esta variación terminológica no sólo implica un paso formal de unas categorías a otras, sino un proceso de descolonización de las mismas categorías de tradición y modernidad, que no hacen otra cosa que reproducir, en el fondo, la ya vieja dicotomía entre un ellos, los salvajes, y un nosotros, los civilizados (Comaroff y Comaroff, 1993). Por el contrario, hacer referencia a las continuidades (del pasado distante) no implica hablar de algo eterno u originario, y hacer referencia a los cambios (del pasado reciente) no implica hablar sólo de occidentalización, urbanización o globalización.

Una sociedad es, entre otras cosas, la compleja fusión y fisión entre los cambios y las continuidades, con distintos cambios y continuidades en una misma área geográfica; o con continuidades asentadas que, en algún punto histórico, fueron cambios incorporados. Una sociedad es el resultado de constantes cambios históricos pasados que han venido transformando y resignificando, de forma periódica, su condición actual. Una sociedad construye continuidades para establecer una estructura con respecto a un pasado histórico adecuado mientras está inmersa en constantes innovaciones, negociaciones y redefiniciones de cambios que traen consigo las diferentes formas de relación con otras sociedades (Hobsbawn, 1983). Hablar de continuidades y cambios es, por eso, reconocer que ambas categorías se encuentran vinculadas entre sí, tanto que no se pueda pensar sobre las continuidades sin pensar sobre los cambios, y viceversa (Appadurai, 1996; Urbano, 1991 y 1997). Por eso, si trabajamos con un concepto esencialista de la cultura (Abu-Lughod, 2012), enfocándonos solamente en las dimensiones tradicionales de la misma, lo que hacemos es construir distancias (pensando que el «otro» siempre está lejos de «nosotros»), diferencias (creyendo que la cultura del «otro» y la de «nosotros» no tienen semejanzas) y jerarquías (asumiendo que solamente «nosotros» podemos construir a los «otros»). 


\section{III.1. Nuevas TIC, preservación cultural y prestigio social}

El 01 de agosto es el inicio de la temporada agrícola y, con ella, el principio de la faena más relevante (llamada Yarqa Aspiy, Yaku Raymi, Fiesta del Agua, Champería o limpieza o escarbo de las acequias principales) en Yanque. Del 01 al 04 en el nevado Mismi, montaña tutelar de Yanque Hurinsaya, y del 07 al 09 en el nevado Waranqanti, montaña tutelar de Yanque Hanansaya. Pero el Yarqa Aspiy de la parcialidad de Hurinsaya no solamente es, en la actualidad, el evento más importante del distrito de Yanque, sino también de todo el Valle del Colca, debido a la mayor cantidad de días laborales, festivos y rituales que conlleva su realización, pues su canal principal de agua (el nevado Mismi) se encuentra más alejado (a $24.5 \mathrm{~km}$ ), mientras que el canal principal de agua de la parcialidad de Hanansaya (el nevado Waranqanti) se encuentra más cerca (a $17 \mathrm{~km})$ de la comunidad (Valderrama y Escalante, 1988).

La importancia del Yarqa Aspiy de Yanque Hurinsaya y Hanansaya radica también -como en otras comunidades colqueñas- en la lucha concreta de muchas autoridades y usuarios, por un lado, por continuar una tradicional identidad cultural que se manifiesta en el compromiso y cumplimiento de su devoción por las divinidades quechuas y católicas; y, por otro lado, por reafirmar y reforzar, ante Coporaque y Chivay, sus derechos legales de usufructo sobre los bienes hídricos, realizando un constante mantenimiento de la infraestructura hidráulica (Gonzales Aguilar, 2016). Asimismo, es interesante destacar que en otras comunidades que cuentan con división bipartita en Hanan y Hurin, el Yarqa Aspiy se realiza unitariamente agrupando a ambas parcialidades (Robles Mendoza, 2010). Eso no sucede en Yanque, donde cada parcialidad tiene un Yarqa Aspiy determinado, ya que las fuentes de riego tanto de Hurin como Hanan son dos diferentes y se encuentran fuera de los límites de su jurisdicción territorial.

\section{III.1.1. EI Rimanakuy o Día de Conversación}

Aunque hubo autoridades políticas prehispánicas de administración pública, tales como el Aqorasi (el anciano venerable), el Llaqtakamayoq (la cabeza de pueblos) o el Tukuy Rikuq (aquel que ve y escucha todo, o aquel que es ojos y oídos del pueblo), la figura del Varayoq (aquel que sostiene la vara), se crea en la segunda mitad del siglo XVI como un cargo cívico-religioso con fines de administración pública colonial (Barrionuevo, 1971). Y fue rápidamente aceptado por la población local indígena, como sucedió con los caciques, no solo porque se anexó al sistema de autoridades hispanas a reconocibles y respetadas autoridades aristocráticas andinas, sino también porque la sociedad indígena había tenido experiencias similares con gobernantes impuestos por el Estado incaico (Ráez, 2001).

Ciertamente, los Varayoq ya no cuidan que los indios hagan sus testamentos, no velan por los huérfanos, no visitan hospitales, no controlan el funcionamiento de los mercados, no vigilan las sementeras ni los ganados, no aderezan los caminos, las iglesias, los tambos ni los puentes, ni cuidan las chacras de los andenes (Barrionuevo, 1971). Indudablemente, los Varayoq ya no siguen subordinados al poder local de la hacienda ni prestando apoyo a las autoridades políticas impuestas por el Estado (Ráez, 2001). Así, pues, aunque el cargo de la figura de Varayoq haya perdido muchas de sus funciones coloniales y republicanas, continuó persistiendo, en tanto cargo cívico-religioso, como Juez de Aguas desde 1902 hasta 1969, cuando, con la Nueva Ley de Aguas No 17752 de la Reforma Agraria de Juan Velasco Alvarado, se oficializan las Comisiones de Regantes y se reconoce estatalmente la figura del Regidor de Aguas, o también llamado en contextos locales, Varayoq, Envarado, Taita Alcalde, Alcalde de Aguas o Yaku alcalde, y como miembro activo del organigrama de las Comisiones de Usuarios hasta la actualidad. 
Dentro del organigrama estructural de las Comisiones de Usuarios, el Yaku alcalde, con todas las responsabilidades que tiene a cargo y desempeña, se encuentra anexado formalmente como parte del área técnica de operaciones y mantenimiento. Aunque, como señalaban Valderrama y Escalante (1988), todavía hoy, y solo para el Ministerio de Agricultura, el Presidente de la comisión de regantes encabeza la estructura jerárquica.

En la comunidad de Yanque, existen dos Comisiones de Regantes, una para Hanansaya y otra para Hurinsaya, como organizaciones representativas de todos los usuarios de agua con fines agrarios de los Sub Sectores de Riego de ambas parcialidades. Los usuarios de agua son todas aquellas personas naturales o jurídicas que cuentan con el derecho de usufructo de agua otorgado por la Autoridad Nacional del Agua (ANA, 2014). Todos los usuarios tienen el deber de pagar una tarifa de agua como contribución económica por metro cúbico del recurso hídrico utilizado en su actividad. El Consejo Directivo de ambas Comisiones de Regantes se encuentra conformado por un presidente, un vicepresidente y cuatro vocales. Pero también por un tesorero, como parte del área de tarifas y cobranzas. No obstante, como parte de la estructura orgánica de la Comisión de regantes, son importantes también las funciones del Vicepresidente y de los Vocales. La función del Vicepresidente es reemplazar al Presidente en caso de haber impedimento, licencia o ausencia temporal del último, ejerciendo sus atribuciones y responsabilidades. La función de los vocales es llevar al día los Libros de Actas de la Asamblea; tener al día los Padrones de Usuarios, los registros y el inventario del patrimonio institucional; y tener al día y vigilar que los libros y documentos de contabilidad estén archivados.

El Presidente de la comisión de regantes es, formalmente, el mediador entre el Ministerio y la comunidad con respecto a temas agrícolas. Es el representante legal de la Comisión de Usuarios del Sub Sector de Riego de cada parcialidad ante las reuniones del Comité de Coordinación del Distrito de Riego, con poder de votación representativa de Hanansaya o Hurinsaya, pero también ante los órganos jurisdiccionales del Poder Judicial. Las funciones del Presidente consisten, por ello, en A). Convocar y presidir las sesiones de asambleas de la Comisión de Usuarios y del Consejo Directivo; y B). Cumplir y hacer cumplir los acuerdos comunales, presentando los informes trimestrales de trabajo, proponiendo las medidas correctivas, suscribiendo las actas de las sesiones y respondiendo solidariamente frente a los usuarios por el daño, abuso de facultades o negligencia grave.

Los usuarios y la Comisión de regantes se reúnen en una Asamblea. La reunión ordinaria tiene como objetivo aprobar todos los Estados Financieros y el programa anual de trabajo y presupuesto del periodo próximo. Por ejemplo, días previos al escarbo de acequia en el nevado sagrado Mismi del 2015, la Comisión de regantes de Yanque Hurinsaya se reunió desde los primeros rayos del sol a debatir y coordinar compromisos para la realización comunal de asuntos agrícolas y rituales (como la gestión respecto de la mano de la obra para el mantenimiento de canales de regadío de Yanque Hurinsaya del 01 al 04 de agosto en el canal Mismi; el 12 de agosto en los canales laterales de la campiña; y el 05 de septiembre en el canal Sifón y el canal Colloni), balances económicos de la caja chica, renovación de alquiler de las tierras comunales, exposición de las rencillas entre usuarios, entre otras cosas, para terminar sellando, lo que se ha pactado colectivamente, tinkando (asperjando y bebiendo un líquido con una divinidad quechua para demostrar respeto, pedir permiso, dar gracias y/o solicitar protección) con gaseosa. Por otro lado, la reunión extraordinaria tiene como objetivo dar conformidad a la cuota propuesta por el Consejo Directivo; aprobar y autorizar la gestión de préstamos y su financiación; aprobar y modificar el Estatuto; acordar la remoción de miembros del Consejo Directivo; establecer la responsabilidad administrativa del Consejo Directivo; y elegir los miembros del Comité Electoral. 
Pero, en la práctica, es el Yaku alcalde el que tiene el mando en la administración del agua. Así, bajo la estructura formal (la que se muestra hacia afuera) subyacen las autoridades tradicionales que dirigen el manejo del agua (que es el válido al interior de la comunidad). Y aunque, a nivel oficial del Estado, la figura del Yaku alcalde solamente tenga importancia cívica (en tanto gestor técnico del agua), en el ámbito local de la comunidad, la figura del Yaku alcalde también tiene importancia política-religiosa; y, por ello, pasar el cargo de Yaku alcalde otorga prestigio social. Podemos ver, así, cómo el Yaku alcalde se desenvuelve en el ámbito formal (autoridades y funciones definidas por una estructura legal de gobierno estatal), el informal (autoridades y funciones definidas por patrones locales de prestigio personal), el interno (códigos culturales de organización específicos de cada autoridad local) y el externo (capacidad de relacionarse con instancias exógenas), al igual que otras autoridades locales dentro de escenarios rurales (Damonte, 2000; Ráez, 2002). Pero la figura del Yaku alcalde es voluntaria solo en apariencia, pues, en el fondo, es obligatoria, debido a la gran inversión en tiempo y dinero, los comuneros se disputan no por pasar el cargo, sino por no pasarlo (Gonzales Aguilar, 2016); y, por todo estos gastos, un cargo aún más valorado socialmente. Por eso los cargos cívico-religiosos son de duración limitada y rotativos, tienen funciones específicas, trajes habituales y atributos determinados, y están jerarquizados entre sí (Diez, 2005).

Desde el punto de vista productivo, el Yaku alcalde es el facultado para regir, a través de un conjunto de normas reglamentarias, el acceso comunal de los usuarios al agua. De esta manera, de acuerdo al Manual de Organización y Funciones de la Comisión de Usuarios de Yanque Hurinsaya (2015), el Yaku alcalde se encarga, principalmente, de A). Llevar el registro de apertura y el cierre de compuertas, así como de los caudales medidos en las tomas a su cargo formulando su parte diario; B). Regular las compuertas de las tomas de los canales de derivación a su cargo, según el rol de distribución; C). Controlar el caudal del agua que discurre por las tomas a su cargo; D). Vigilar que las compuertas de las tomas a su cargo no sean operadas por personas ajenas; E). Efectuar labores de limpieza de las tomas de captación a su cargo e informar cuando estas labores requieran de la participación de los usuarios; F). Mantener en buen estado los precintos y demás sistemas de seguridad de las tomas; G). Efectuar el reparto diario de agua de acuerdo al rol de riego de distribución que establezca el Jefe de Sector o Sub Sector de Riego; H). Elaborar los partes diarios de distribución de agua por usuario y por predio; I). Controlar las limpiezas y reparaciones de los canales, tomas, drenes y caminos de vigilancia de su zona de trabajo, así como de las reparaciones de las obras de conservación y control de inundaciones; J). Informar sobre las infracciones en la distribución y aprovechamiento del agua, así como de los problemas de manejo de agua y del suelo; K). Colaborar en la distribución y recepción de solicitudes de plan de cultivos para plan de riegos; L). Informar a los usuarios sobre eventuales cortes de agua, ya sea por limpieza del canal principal, por alguna obra de canalización u otro motivo.

Desde el punto de vista ritual, el Yaku alcalde es el facultado para acercar a los comuneros (lo humano) con el agua, la tierra y las montañas (lo divino). Precisamente por ello no es coincidencia que la palabra quechua Yaku se utilice para denominar al agua en tiempos profanos, mientras que la palabra aymara Mallku, aunque signifique antepasado, se utilice para denominar al agua en tiempos sagrados.

En la comunidad de Yanque, existen cuatro Yaku alcaldes, dos para la parcialidad de Hanansaya (con propiedad de las varas de Waranqanti y Ticlla) y dos para la parcialidad de Hurinsaya (con propiedad de las varas de Mismi y Sifón). Y todo comunero que tenga más de cinco topos de tierra tiene la obligación de pasar por el cargo de Yaku alcalde si es que este 
es solicitado por el resto de usuarios. Esta obligación de compromiso y colaboración exime al Yaku alcalde de recibir un pago formal, aunque sí se le brinda una ayuda simbólica por parte de los miembros de la Comisión de regantes (para los gastos que aparecen en el ejercicio de sus funciones como gestor del recurso hidráulico) y una retribución simbólica por parte de los demás comuneros (por los gastos que requiere el desempeño de sus funciones como responsable del ritual y organizador de la fiesta).

El 31 de julio de 2015 se llevó a cabo el Rimanakuy en la casa del Yaku alcalde (Gil Rivera, 52 años), una celebración ritual donde el mismo Yaku alcalde y otras autoridades, tales como el Kamachikuq Yana (especialista, Isidro Suni, 65 años), el Rikuy (servidor del Yaku alcalde, Mauro Inca, 41 años) y el Kamachikusqa (ayudante del Yana, Sixto Suni, 43 años), construyen doce Irantas (hechas de sebo de alpaca o llama, maíz, incienso, pepas y lafras u hojas enteras de coca, y cunuja, entre otros elementos rituales) que son quemadas para saludar, pedir permiso y bendiciones para el camino y la estadía al Tata Mismi, al Tata Waranqanti y al Tata Colca, así como agradecimientos al padrino, la madrina, al Niño Manuelito y a las dos varas sagradas del Yaku alcalde. En la tarde de ese día, el Yaku alcalde y su familia preparan pan y humitas con queso, y limpian y acomodan su casa para poder recibir a los usuarios de la parcialidad de Hurinsaya a partir de las seis de la tarde. Todo ello en vísperas a la madrugada siguiente, cuando la comunidad parte rumbo al nevado sagrado Mismi para trabajar, festejar y ofrendar por tres noches y cuatro días al Tata Mallku y a la Mama Pacha.

Desde la misma tarde del Rimanakuy pudimos observar los usos de las nuevas TIC en los contextos rituales de Yanque. Comenzó con la presencia del joven hijo del Yaku alcalde (del 2015), a quien su padre le había pedido que grabe para poder después mostrárselo al resto de la familia que no iba a poder asistir al evento. Así, por ratos con una filmadora y por ratos con su celular, él seguía a todos. Desde las escenas más privadas hasta las más públicas, todas las grababa. Cuando aún nadie llegaba, seguía a su madre, la esposa del Yaku alcalde, mientras preparaba la comida para todos los comuneros que iban a asistir a la reunión de la noche. Seguía con la filmadora y con el celular a su tío, hermano del Yaku alcalde, mientras preparan pan y humitas con queso, y mezclaba los baldes de almidón y alcohol para compartirlo en la noche con los usuarios. Grababa, asimismo, el lento proceso de cómo el Yaku alcalde, el Kamachikuq Yana, el Rikuy y el Kamachikusqa construían las Irantas. Grababa cómo vestían al niño Manuelito (una adaptación del Niño Jesús para el mundo andino, y cuya representación es acompañada por un sombrero, un traje de colores y una vara a escalas). Grababa también cómo se sahumaban las dos varas del Yaku alcalde (Juan de la Cruz y Presentación) para limpiarlas y cómo se las vestía para que no sientan frío cuando una de ellas sea llevada a la montaña. Grababa, por último, al Yaku alcalde, al Presidente de la comunidad, al Presidente de la comisión de regantes de la parcialidad de Hurinsaya y al Alcalde Municipal sentados en la misma mesa frente a los demás comuneros y usuarios de Yanque, al caer la noche, coordinando los pormenores para la ida al nevado Mismi esa misma madrugada, y brindando, entre ellos, con almidón y chicha de maíz y cebada.

Durante todo el Rimanakuy, tanto el Yaku alcalde como su hijo señalaban que el objetivo de grabar estas escenas era el de preservar las costumbres de la cultura yanqueña para que no se pierdan. Entonces, en ese contexto, las nuevas TIC estarían -porque veremos que, en el fondo, no se trata solo de eso- siendo usadas para registrar audiovisualmente una tradición ritual para perpetuarla, porque, además, se veía amenazada, de acuerdo al Yaku alcalde, en desaparecer por la influencia de agentes exógenos como la carretera y el turismo. Y es que aunque esas costumbres aún están vivas en la comunidad, la necesidad de preservarlas surge de una percepción de un creciente retroceso de las mismas. 
Si bien es cierto que una carretera (la asfaltada) ha contribuido al incremento del turismo en la comunidad, otra carretera (la asentada) afecta también actividades tradicionales del calendario social yanqueño, como la fiesta laboral del 01 al 04 de agosto en el nevado Mismi. Los yanqueños adultos recuerdan, con nostalgia, que antes de la posibilidad de llegar al Mismi en automóvil por la carretera asentada del 2014, importaba no solo la estadía en la montaña, sino también la llegada, el camino que se transitaba con los burros, y todas las vivencias que luego se narraban al regreso en el pueblo: desde el helado frío, la caída de la carga, los desmayados en el camino, hasta los embarcados de vuelta en caballos por los macho-arrieros. "Ahora ya solo importa llegar en carro» - señalaba el Yaku alcalde y muchos, que, como él, temen que el ritual se pierda en menos de una década, no solo por el poco compromiso que, aseguran ellos, le encuentran las nuevas generaciones a esta práctica, sino también porque las autoridades políticas locales han comenzado a cuestionar la utilidad productiva de lo mágico-religioso de los rituales, y, por esta razón, proponen adaptar una lógica de redistribución colectiva y pública del trabajo a una lógica de contratación individual y privada del trabajo; en otras palabras, proponen que la labor de limpieza de acequias, hasta ahora realizada por la comunidad, conviva, desde ahora, con la labor de obreros asalariados. De hecho, desde el 2017, se cobra a todos los comuneros tres soles por topo en todas las faenas comunales (excepto la del Mismi, del 01 al 04 de agosto) para que peones contratados se ocupen de la limpieza de los canales. Aunque para los trabajos de la limpieza de acequias en el Mismi, también existen comuneros que prefieren enviar peones (un peón por cada ocho topos de tenencia de tierra) y/o pagar una multa pecuniaria (ochenta soles por topo de tenencia de tierra), pues se encuentran insertos en una mayor pluriactividad económica y, por lo tanto, tienen menos tiempo para dedicarse de manera exclusiva a la agricultura y sus requerimientos. No obstante, por lo menos hasta ahora, muchos en la comunidad no quieren que la tradición del Yarqa Aspiy se detenga. "Es costumbre. Hay que seguir manteniéndola", dice el Kamachikuq Yana, así como dicen también muchos comuneros viejos de Yanque, aludiendo que esa tradición es parte de la identidad que les han dejado sus abuelos; así, si esta tradición se pierde, ellos pierden también su identidad o, por lo menos, la vigencia de su identidad heredada del pasado. En ese sentido, parece ser que tradiciones como el Yarqa Aspiy funcionan, entre otras cosas, como un nexo que los comuneros de Yanque, sobre todo los adultos, preservan para no desvincularse de la cultura de sus padres, abuelos y demás ancestros.

Entonces, todo parecía indicar que el Rimanakuy era una oportunidad para que las nuevas TIC posibilitaran que se graben todas esas escenas con el fin de preservar y perpetuar audiovisualmente una tradición para que no sea olvidada. Y es que los yanqueños que utilizan el audio y el video son muy conscientes de su funcionalidad -la imagen que no se pierde, que no se desgasta, que puede ser vista y oída aquí y allá- para conseguir su objetivo de conservar una parte de su cultura. Sin embargo, unas semanas después tuvimos la oportunidad de ser invitados por el Yaku alcalde a su casa, para ver, con su familia, estas grabaciones. Y nuestra impresión cambió. Sabíamos ya que pasar el cargo de Yaku alcalde otorga prestigio social, ya que, desde el punto de vista productivo, el Yaku alcalde es el facultado para regir, a través de un conjunto de normas reglamentarias, el acceso comunal de los usuarios al agua, pero también, desde el punto de vista simbólico, el Yaku alcalde es el facultado para acercar a los comuneros (lo humano) con el agua, la tierra y las montañas (lo divino). Y aunque, a nivel oficial del Estado, la figura del Yaku alcalde solamente tenga importancia cívica (en tanto gestor técnico del agua), a nivel local de la comunidad, la figura del Yaku alcalde también tiene importancia ritual.

Por eso comprendimos que, en ese contexto, grabar no solamente significaba un acto de preservación cultural, sino también un registro del prestigio social. Nos sentamos al pie de la cama y miramos cómo ellos, el Yaku alcalde y su familia, se veían a sí mismos. Todos observábamos el 
video cuando, de pronto, el Yaku alcalde dijo «con esto [la grabación] recordaré que alguna vez fui Regidor [de Aguas] y cumplí humildemente con mi cargo dando nuestra casa y nuestro tiempo para nuestros hermanos [comuneros]». También le pidió a su hijo que cuelgue el video en Internet para que sus familiares que no habían asistido puedan ver «que he sido Regidor [de Aguas] y que hice algo por nuestro pueblo». Así, a través de las grabaciones no solo se conservaba una tradición cultural, sino que también se registraba y se circulaba el prestigio social que había obtenido el Yaku alcalde por haber pasado el cargo. Y es que el cargo era tan importante para el Yaku alcalde que nos pidió que le tomáramos fotos a él cumpliendo sus obligaciones rituales durante los cuatro días que estuvimos en el Mismi. Después, cuando le entregamos las fotografías impresas, las colgó en la pared en el comedor de su casa, junto a las dos varas y al niño Manuelito.

\section{III.1.2. EI Varamaya o Limpieza de Vara}

No solamente en el Rimanakuy encontramos el uso de nuevas TIC para la preservación de la cultura y el registro del prestigio social. Otro contexto ritual en donde también aparece este mismo uso lo hallamos en el Varamaya. Ese día, 01 de enero, las autoridades políticas y religiosas, después de haber subido al Mismi para hacer el Pagachi (pagos rituales al agua, la tierra y las montañas) el 31 de diciembre de cada año, se reúnen en las casa del Yaku alcalde (del 2016) para realizar la costumbre de limpiar la vara con alcohol.

Pero si el Yaku alcalde es el sujeto intermediario entre lo profano y lo sagrado, la vara es el objeto intermediario entre la comunidad y el Tata Mallku y la Mama Pacha. Por ello es que la vara tiene nombre (bautizadas como Juan de la Cruz y Presentación, en Yanque Hurinsaya; y como Tomás y Guardia Civil, en Yanque Hanansaya). Aunque, de acuerdo con Valderrama y Escalante (1988), existen otros nombres de bautizo para las varas que se encuentran relacionados a fechas centrales del calendario religioso católico: por ejemplo, el 25 de diciembre, se les denomina Manuel (por Jesús); el 01 de enero, se les denomina Silvestre (por San Silvestre); y el 02 de febrero, se les denomina Tomás (por la Virgen de la Candelaria). Asimismo, la vara también tiene cuerpo (una vez sahumada para limpiarla, es vestida para que no sienta el frío de la montaña y adornada con wayta, planta que también adorna los sombreros de los comuneros más importantes), y tiene condición (guardada en un altar al interior de la casa): en definitiva, tiene vida propia. Tanto así es la relevancia social de la vara en Yanque que, después del ascenso al Mismi para hacer el pagachi el 31 de diciembre de cada año, las autoridades económicas, políticas y religiosas se reúnen en la casa del Yaku alcalde para llevar a cabo el tradicional varamaya o limpieza de la vara (con alcohol).

La vara es una insignia de mando precolombina, aunque a partir del periodo colonial, con el cargo de Varayoq, la vara, hecha de madera y metal, posee símbolos sincréticos religiosos tanto católicos (el crucifijo) como quechuas (el sol, la luna, las plantas y los vegetales, así como también figuras geométricas). Por eso, las varas son bendecidas en la iglesia por los curas, reconociendo el poder que han detentado por siglos y marcando el inicio del año de regiduría, sin posibilidad de reelección del Yaku alcalde. Y, por eso, la vara como símbolo de autoridad local (Arguedas, 1985; Valderrama y Escalante, 1988; Ramírez León, 2014), posiciona al Varayoc (aquel que sostiene la vara) no solo como Yaku alcalde (Alcalde o Regidor de Aguas), sino también como el representante comunal en contextos rituales: no solo comunica a la comunidad con la naturaleza a partir de la productividad, sino también a partir de lo ritual, actualizando, con ayuda de un Kamachikuq Yana (el especialista), de un Rikuy (el servidor del Yaku alcalde) y de un Kamachikusqa (el ayudante del Yana), las costumbres político-religiosas andinas, constituyendo así la memoria viva que hace posible la persistencia de conocimientos ceremoniales. 
En este escenario se insertan las nuevas TIC. Así como sucedió con el Yaku alcalde del año anterior, en esta ocasión también es el hijo del Yaku alcalde (del 2016) quien se encuentra encargado de grabar con su celular todas las escenas de la ceremonia. Este elemento generacional es una recurrencia importante en el uso de las nuevas TIC en Yanque, ya que los niños y jóvenes se encuentran mejor capacitados que los adultos para el uso del Internet y el celular. Pero, curiosamente, son los padres los que hacen que los niños y jóvenes formen parte de las fiestas y rituales dándoles el cargo de fotografiar o filmar, logrando, a través de esta acción pedagógica, que las nuevas generaciones se socialicen y aprendan los conocimientos de dichas prácticas sociales.

Entonces, en el Varamaya, se bebía chicha, se comía, se bailaba, pero lo más importante era que todas estas actividades se desarrollaban alrededor de la mesa central donde el Yaku alcalde se encontraba sentado, al lado de otras autoridades políticas, como el Alcalde Municipal, y religiosas, como el Kamachikuq Yana, el Rikuy y el Kamachikusqa. La gente del pueblo hacía cola hasta afuera de la casa para poder agradecer económicamente al Yaku alcalde. Y es que el cargo de Yaku alcalde, una obligación de compromiso y colaboración, si bien no recibe un pago formalmente establecido de dinero (como si se tratase del pago de un sueldo en una relación contractual), sí recibe la suma variable de las voluntades económicas de los comuneros. Así, pues, el Yaku alcalde fue compensado por los miembros de la Comisión de regantes (para los gastos que aparecen en el ejercicio de sus funciones como gestor del recurso hidráulico) y por el resto de comuneros (para los gastos que requiere el desempeño de sus funciones como responsable del ritual y organizador de la fiesta). La compra de alcohol, para la limpieza de la vara, se encontraba dividida entre mayoristas (quienes poseen más de cinco topos de tierra), que compraban la mayor cantidad de alcohol, y minoristas (quienes poseen menos de cinco topos de tierra), que compraban apenas una pequeña botella de alcohol o alcohol en bolsa. Entonces, alrededor de la mesa, mientras unos ancianos ya estaban ebrios y las mujeres comían, los usuarios hacían fila para rendir sus respetos ya no solo al Yaku alcalde, sino, y sobre todo, a la vara. Uno a uno iban vertiendo la cantidad de alcohol que habían comprado sobre la vara que sostenía el Rikuy (asistente del Yaku alcalde). El hijo del Yaku alcalde (del año 2016) seguía con su celular cada una de estas escenas porque - como afirmaba él- «hay que mantener nuestras costumbres». Y en todas estas escenas públicas, el Yaku alcalde siempre se había mostrado orgulloso, pues no era ningún secreto que este cargo es una forma de autoridad local que otorga estatus a quien lo pasa. Ese orgullo se evidenciaba en la solemnidad que desplegaba cuando se dirigía, al resto de usuarios y comuneros, como un líder. O cuando recibía, célebre, los aplausos de las autoridades políticas y religiosas no solo durante el tiempo que duró el Varamaya, sino también, el día anterior, cuando estuvieron en el Mismi para realizar la costumbre del Pagachi. Ciertamente, la preservación de la tradición cultural era el objetivo más evidente e, incluso, explícito, pues tanto el Yaku alcalde como su hijo señalaban la importancia de que no se pierdan los elementos tradicionales de su cultura. Pero, como sucedió en el caso anterior, las fotografías y videos no solamente servían para perdurar la tradición cultural sino también para registrar el prestigio social que el Yaku alcalde había obtenido como pasante del cargo productivo-ritual y como auspiciador del Varamaya.

\section{III.1.3. EI Puqllay o Fiesta de Carnavales}

Finalmente, encontramos estos mismos usos de las nuevas TIC en el Puqllay o la Fiesta de Carnavales, que se celebra durante toda la última semana de febrero, y donde compiten la parcialidad de Yanque Hurinsaya y Yanque Hanansaya, siendo una fiesta que involucra a gran parte de la comunidad. 
La dualidad entre Hanan y Hurin se encuentra todavía vigente en Yanque, y tiene como punto central de referencia a la iglesia de la comunidad, desde donde se marca una división espacial y simbólica entre los residentes de Hanansaya y Hurinsaya (Cook, 2011), comprometiéndolos a participar en las labores, fiestas y rituales de su respectiva parcialidad (Valderrama y Escalante, 1988; Benavides, 1991). La vigencia de la división Hanan (este-superior) y Hurin (oeste-inferior) aparece en el cementerio de la comunidad, donde cada parcialidad ocupa una mitad específica del cementerio (Benavides y Llosa, 1994), donde solo a partir de mediados del siglo XIX, por ordenanza obispal nacional, comenzaron a ser sepultados los fieles, pues antes los entierros se realizaban dentro de los templos, atrios y conventos (Benavides, 1988). Pero esta división dual también está vigente en el hecho que cada parcialidad tenga que manejar un sistema hidráulico de forma independiente (Ráez, 1998), con conflictos con respecto a tomas comunes, un problema que no existía prácticamente hasta que se abolió el cacicazgo, cuando el control de riego era todavía un asunto provincial (Bernal, 1983; Benavides, 1988). Y recordemos también que, en la actualidad, el canal principal de riego de Yanque Hanansaya (cuyas tierras agrícolas se encuentran junto al pueblo) y de Yanque Hurinsaya (cuyas tierras agrícolas se encuentran frente al río) son, respectivamente, las aguas del nevado Waranqanti y del nevado Mismi. No obstante, actualmente, la parcialidad de Yanque Hanansaya no solo cuenta, para el riego agrícola, con el canal Waranqanti, sino también los canales Ticlla, Sifón y Majes. Este hecho hace que dicha parcialidad tenga mucho menos problemas con el agua de riego que la parcialidad de Hurinsaya, y, tal vez, sea esta necesidad que hace que los pobladores de Hurinsaya estén mucho mejor organizados con los trabajos, fiestas y rituales. Y, por último, vale mencionar que el hecho que un comunero sea reconocido como parte de y que posea tierras en una parcialidad específica Hurinsaya o Hanansaya- no lo excluye, en la práctica, de tener topos en la parcialidad a la que formalmente no se encuentra adscrito.

Todos los años, una familia se devota, en calidad de alferados, para pasar el cargo de hacerse responsable por la fiesta y todo lo que ello implica: contratar a las bandas de músicos, preparar la comida, hacer la chicha de maíz y cebada, asegurarse que la gente se comprometa a bailar Wititi durante todo el día y la noche, entre otras cosas. Tres hermanos de la familia Suni se habían comprometido con la comunidad para hacer posible la realización del Puqllay a fines de febrero de 2017.

Tuvimos la oportunidad de asistir, temprano por la mañana, a la casa de los alferados y mirar cómo ellos, sus parientes y amigos se vestían, hombres y mujeres, con los trajes del baile del Wititi -una danza reconocida por la UNESCO, en 2015, como patrimonio cultural inmaterial de la humanidad-presente en muchos distritos del Valle del Colca, aunque en Yanque adquiere un propio estilo performativo, desde la vestimenta hasta el baile (según yanqueños de mayor edad, el Wititi, donde los hombres usan faldas y antifaces coloridos, tenía una doble función: por un lado, como una danza para sacar a las mujeres de sus casas con engaños y sin que sus padres se percataran de ello; y, por el otro, como una danza para confundir a los enemigos en batalla). Tuvimos también la oportunidad de ver llegar a las dos bandas de música y de escucharlas, desde sus inicios, interpretar las melodías del Wititi y mirar a la gente comenzar a bailar con mucha felicidad. No obstante, creemos que la oportunidad más aprovechable que tuvimos fue la de observar cómo la familia había contratado, días atrás, en Chivay, a alguien que grabara los pormenores de toda la fiesta, desde la mañana hasta la madrugada. El fotógrafo-filmador no sólo sugería posturas a los alferados, sus parientes y amigos para ser fotografiados, también los orientaba a que le hablen a la cámara. Los tres alferados mandaban saludos a aquellos parientes que no pudieron estar en Yanque para esos días de fines de febrero. Los tres hermanos señalaban que habían contratado a esta persona porque «son costumbres de nuestros abuelos que se están 
perdiendo». La cámara de foto y video tenía, entonces, el objetivo de registrar las costumbres para preservarlas. Al mediodía, los alferados, sus parientes y amigos, al ritmo de ambas bandas de música tocando Wititi, se fueron danzando hasta la plaza del pueblo para comenzar, después de hacer las correspondientes reverencias a la iglesia de Yanque, la competencia entre parcialidades que duró hasta la madrugada. Cada parcialidad estaba representada por una cuadrilla de músicos y danzantes, ubicados una frente a la otra en el centro de la plaza de la comunidad. Competían - como ellos mismos señalaban- por ver y mostrar qué cuadrilla bailaba mejor y tocaba más fuerte, y, por ello, qué parcialidad era mejor que la otra. Desde la tarde hasta la noche, lo que estuvo en juego simbólico fue el prestigio social de las parcialidades de Hurinsaya y Hanansaya.

Pero esta búsqueda de prestigio social no podría haber sido posible sin los alferados. El hecho que los yanqueños de Hurinsaya hayan podido competir para conseguir estatus se encuentra relacionado con el hecho que los hermanos Suni hayan donado ambas bandas de música y conseguido los danzantes. Los responsables indirectos del prestigio social que, de hecho, llegó a ganar la parcialidad de Hurinsaya fueron quienes otorgaron las condiciones para que ese estatus sea buscado y ganado. En ese sentido, el registro de las costumbres y de las tradiciones culturales de Yanque en fotos y videos comprende sólo una parte del uso de las nuevas TIC en este contexto festivo. Creemos que la otra cara del uso de las fotos y el video es -ya que las grabaciones se centraron principalmente en los alferados desde la mañana hasta la madrugada- registrar también el poder de los hermanos Suni para hacer realizable no solo la tradicional Fiesta de Carnavales, a donde acude gran parte de la comunidad, sino, también, para hacer que su parcialidad pueda competir y ganar estatus.

\section{III.2. El registro audiovisual como evidencia político-legal}

No solo los faenantes y las autoridades rituales tomaban y se hacían tomar fotos durante todo el trayecto de los cuatro días de trabajos, fiestas y rituales del Yarqa Aspiy del 2015. También los representantes de la Municipalidad Distrital de Yanque y el Presidente de la comunidad, con cámaras fotográficas y de video registraron los momentos centrales del Yarqa Aspiy. El Presidente de la comisión de regantes de Yanque Hurinsaya utilizaba lo escrito (un cuaderno) para llevar el registro y el control diario de la asistencia de los faenantes que había mandado cada unidad doméstica de dicha parcialidad. Pero tanto para la Municipalidad Distrital de Yanque como para el Presidente de la comunidad, las herramientas de registro no eran escritas, sino digitales. Ambos usaban lo audiovisual (las cámaras de fotografía y video) para el registro de los acontecimientos centrales.

\section{III.2.1. EI Alcalde Municipal y los asuntos comunales}

El Alcalde Municipal es el elegido por el pueblo como intermediario entre la comunidad y el Estado y otros contextos oficiales. No obstante, muchos alcaldes municipales no han sido usuarios ni comuneros activos dentro de ambas parcialidades; por el contrario, solo aquellos que tienen escolaridad completa y otros títulos educativos y, crucialmente, aquellos que se han relacionado fuertemente con la ciudad de Arequipa, pueden acceder al cargo de Alcalde Municipal. Y es precisamente por su identidad social de no ser un miembro activo dentro de las actividades productivas yanqueñas, que el Alcalde Municipal es percibido como liminal. Y, por eso, se comprende que la relación entre la municipalidad y la comunidad sea una de contrapartida. Por ejemplo, las obras de construcción se realizan con la mano de obra que dispone la Comisión de regantes y con el material que brinda el Municipio. En una ocasión, se derrumbó un canal de regadío y, para repararlo, la Comisión de regantes otorgó mano de obra y el Municipio concedió 
herramientas, cemento y movilización. Por eso, la comunidad de Yanque también se encuentra inserta, aunque en menor medida de dependencia, en una economía estatal representada por el cargo político electivo de Alcalde Municipal. Sin embargo, como sucede con el resto de los cargos políticos, aparecen alrededor de este reclamos de falta de compromisos y colaboraciones, aunque habría que añadir que sobre este específico cargo político han proliferado el deterioro y la pérdida de la legitimidad del gobierno local sobre la representación de intereses comunales (Diez, 2001b); pero además habría que señalar que, para muchos comuneros, el cargo de Alcalde Municipal constituye el cargo político más difícil de fiscalizar, pues, a diferencia del resto, se ejerce muchas veces fuera de la comunidad.

Para el Alcalde y para sus representantes, el registro audiovisual de los trabajos, fiestas y rituales del Yarqa Aspiy era una evidencia de que la Municipalidad Distrital muestra, por un lado, interés por las actividades de la comunidad, y, por otro lado, compromiso, ya que enviaron faenantes, a título personal del Alcalde Municipal, para que colaboren con los trabajos de limpieza de acequias, asegurando así una prueba del cumplimiento de su obligación política con el pueblo. De hecho, este uso de las nuevas TIC se hace cada vez que hay un trabajo colectivo de la comunidad a donde el Alcalde envía faenantes en representación. La Municipalidad Distrital usa lo audiovisual, registrando el interés y el compromiso de la misma, para reforzar la idea de presencia municipal en los asuntos de la comunidad, ayudando así a mejorar las relaciones con el pueblo de Yanque.

Y, como sucede con otros cargos políticos, aparecen alrededor de este reclamos de falta de compromiso y colaboración, aunque sobre este específico cargo político han proliferado, y, en general, para toda la institución (Diez, 2001b), el deterioro y la pérdida de legitimidad del gobierno local sobre la representación de intereses comunales. En ese sentido, no es difícil comprender porqué es importante para la Municipalidad Distrital mostrar interés por los asuntos de la comunidad, fotografiando y grabando los trabajos, fiestas y rituales, pero también porqué es necesario fotografiar y grabar la presencia de sus propios representantes faenantes colaborando con la limpieza de acequias, ya que ambas posicionan a la Municipalidad Distrital en una relación de menor tensión y conflicto con la comunidad, y es por eso que necesitan ser registradas con fotos y videos.

\section{III.2.2. EI Presidente de la comunidad y el mantenimiento hidráulico}

En Yanque, a partir de la Ley General de Comunidades Campesinas promulgada en 1987, existen dos Presidentes de la Comunidad: uno para la parcialidad de Hanansaya y otro para la parcialidad de Hurinsaya. En tanto cargo rotativo, es obligación de todo comunero activo que reside en el distrito y que es elegido por el pueblo en elecciones comunales para representar a cada parcialidad, cumplir con la función de realizar cambios en beneficio del pueblo de acuerdo con el estatuto de la Comunidad Campesina, y con la función de administrar los recursos económicos de la comunidad. En ese sentido, si la Comisión de regantes rige sobre el agua, la Comunidad Campesina rige sobre la tierra. De esta manera, el Presidente de la comunidad asiste a todas las asambleas con el objetivo de comprender las necesidades comunales con relación a la actividad agropecuaria, pero también sobre otros proyectos productivos, como la actividad turística, que impliquen el desarrollo de relaciones con entidades exógenas (hacia afuera de la comunidad de Yanque), desde la búsqueda de presupuesto económico en el Municipio y en el Estado hasta la asesoría legal sobre temas medioambientales.

Para el Presidente de la comunidad, las imágenes registradas sirven como una evidencia del constante mantenimiento de la infraestructura hidráulica que hacen los yanqueños de Hurinsaya, 
y por ello, también como estrategia narrativa, e incluso como argumento legal, para reforzar su legítimo derecho de acceso y usufructo del agua del nevado Mismi.

La marcación de la diferencia entre las identidades intercomunales constituye también un elemento importante para ubicar a Yanque y a los yanqueños dentro del Valle del Colca. Un fin de semana de julio de 2015, durante la fiesta patronal en honor al apóstol Santiago, en el distrito de Coporaque, a treinta minutos en automóvil desde Yanque, un hombre de la orquesta, al ver a yanqueños en medio del baile de los turcos, la comida y la bebida de la plaza, dijo por el altoparlante: «¡Aquí hay gente de Yanque! ¡Que salgan a bailar esos ucños!». A los yanqueños se les denomina ucños porque se les percibe como humildes y benevolentes, en apariencia, pero traicioneros, en el fondo porque «robaron» el agua de otros distritos. Otra denominación interdistrital que también se utiliza para referirse a los yanqueños es mañay yaku, haciendo alusión al agua prestada. Pero, hay que comprender que ambos términos quechua se encuentran teñidos de dichas connotaciones a raíz de los conflictos y las rivalidades por la propiedad y el acceso entre las comunidades de Yanque Hurinsaya y Coporaque, por las aguas del Mismi, que datan desde 1890, y pasan por la existencia de los documentos de 1897 y 1925, hasta la batalla interdistrital en Chachayllo, en 1971, finalizando con el fallo favorable para Yanque Hurinsaya, en 1972, a partir de la victoria motivada por la muerte de uno de sus miembros a causa de la piedra lanzada por la waraka de un coporaqueño (Benavides, 1998). Por eso, desde ese entonces, en Chachayllo, se realizan rituales en conmemoración a la muerte de Jesús Montalvo Suni.

La importancia de la agricultura de la comunidad de Yanque no solo se manifiesta en el ritual, sino también en el ámbito mitológico. En la comunidad de Yanque, Gonzales Aguilar (2016) ha encontrado que ciertos mitos agrícolas se usan como estrategias narrativas para legitimar el derecho de acceso al agua, e incluso como argumentos legales, si recordamos que los comuneros de la parcialidad de Yanque Hurinsaya apelaron al usufructo milenario que habrían hecho sus antepasados sobre las aguas del Mismi, que se encuentra dentro de la jurisprudencia territorial de la comunidad de Coporaque, para obtener el reconocimiento del Estado para la administración y gestión comunal de este bien hídrico.

Valderrama y Escalante (1988) observaron que la comunidad de Yanque es -como otras del Valle del Colca y de los Andes- una sociedad hidráulica; es decir, es una sociedad que se organiza colectivamente en torno al agua, la tierra y las montañas. Estas condiciones materiales de producción (la agricultura como una actividad de subsistencia) son las bases infraestructurales de instituciones superestructurales (los mitos y los rituales en torno al agua, la tierra y las montañas). Así, Valderrama y Escalante (1997) encuentran varios mitos yanqueños etiológicos que inciden en la importancia social del agua, entre los que se cuentan el relato del Inca Maita Ccápac en el Valle del Colca, donde se narra cómo el rechazo al inca por parte de los yanqueños de entonces le costó a la comunidad un acceso limitado al recurso hidráulico; o el relato del Origen de las aguas de Hanansaya Yanque, donde se narra cómo el cacique Juan Gualberto Choquehuanca de Yanque Hanansaya llevó, ayudado por mil hombres, el agua del cerro Waranqanti a dicha parcialidad a pedido de la princesa Sumaq Huayta, a quien había desposado para vivir en esta comunidad que hasta ese entonces carecía del recurso hidráulico (aunque existe otra versión yanqueña de este mito, donde es el kuraka Usqay Maqta de Yanque Hanansaya quien desposa a la princesa Sumaq Huayta, y donde esta es hija del cacique Juan Gualberto Choquehuanca. Pero, como en la primera versión de este mito, el agua del cerro Waranqanti es llevada, por mil hombres, a Yanque Hanansaya, a pedido y como condición de la princesa para casarse y vivir en esta parcialidad, que, a partir de ese entonces, obtuvo el acceso al agua). 
Actualmente, ambos mitos son usados por los comuneros de Yanque Hanansaya, a raíz de los conflictos y las rivalidades por la propiedad y el acceso entre dicha parcialidad y Chivay por las aguas del nevado Waranqanti, para reafirmar, como los yanqueños de Hurinsaya, sus derechos de usufructo de agua reconocidos legalmente por el Estado en el siglo XX. En el año 2014, durante el último día del Yarqa Aspiy, pudimos recoger una versión diferente de ambos mitos narrados por faenantes de Yanque Hanansaya. Mientras descendíamos de la montaña, siguiendo los pasos de la banda de música y de la jerarquía política hacia la plaza del pueblo, abrazados en la oscuridad de la noche y un poco embriagados por la chicha de maíz y cebada que se había helado con el intempestivo descenso de temperatura, ellos dijeron: «¿Ves esa montaña? Es Waranqanti. El Inca trajo sus aguas para acá y se casó con una yanqueña. El Inca nos dejó esas aguas. Se las quitó a Chivay y nos las dio a nosotros» (Édgar Tinta, 46 años).

Ahora ya no solo estos mitos orales sirven para legitimar ese derecho, sino también las imágenes que fotografió y grabó el Presidente de la comunidad durante los cuatro días en el Mismi de 2015. Sin embargo, para mantener el acceso y usufructo legal de las aguas del Mismi, los yanqueños de Hurinsaya tienen que demostrar a los coporaqueños, de forma permanente, que utilizan y preservan su infraestructura hidraúlica. Así, por un lado, las imágenes de los faenantes de cada unidad doméstica limpiando las acequias eran registradas por el Presidente de la comunidad porque estas serían usadas como prueba de que los yanqueños de Hurinsaya no sólo aprovechan sino que también conservan los canales de agua del nevado Mismi. Y, por otro lado, las imágenes de las autoridades políticas y religiosas haciendo Tinkachis durante todo el recorrido desde el Mismi a la comunidad de Yanque eran registradas por el Presidente de la comunidad porque estas ponían en evidencia que, paralelamente a una productividad colectiva, se construía una religiosidad colectiva en torno a la tierra, al agua y las montañas, hecho que reforzaba, de manera espiritual, el uso y conservación del bien hídrico.

\section{III.3. El celular en contra de la tradición}

Los usos de las nuevas TIC en los escenarios rituales yanqueños no se encuentran libres de resistencias ni oposiciones de cierto sector de la comunidad, sobre todo cuando se trata de contextos cuya realización anual es vital para la reafirmación de la continuidad de una costumbre.

\section{III.3.1. Los hombres y el agua: la eficacia simbólica de un ritual}

Durante el cuarto y último día del Yarqa Aspiy, todas las autoridades políticas y religiosas, y los faenantes descendían a pie por un trayecto de cuatro horas para encontrarse con sus familiares y el resto del pueblo a las afueras de la comunidad. El objetivo era, como marcaba la costumbre, bajar la montaña corriendo paralelamente al agua que se había dejado correr por los canales de riego. Pero en una parada, después de almorzar, un comunero joven alzó la mano y propuso bajar caminando, no corriendo, para así evitar que se puedan tropezar y caer. Y propuso una eficiente solución para que el agua que corría hacia abajo no llegase, mucho antes que los comuneros, a donde estaban ya esperando sus familias y el resto del pueblo. La solución propuesta era cerrar la compuerta en el lugar donde se encontraban y que un faenante permanezca allí hasta que los demás estén a una distancia considerable antes de llegar al punto de encuentro, donde se le llamaría por celular para que recién libere el agua y así ambos, los hombres y el agua, puedan aparecer juntos frente a todos. Parecía, pues, una eficaz propuesta. Pero ante las miradas de las autoridades políticas y de los faenantes viejos, aquella consistía en una propuesta absurda que amenazaba con atentar y cortar la continuidad de una costumbre yanqueña. ¿Por qué? Porque si la eficacia del 
ritual radicaba, por un lado, en que los hombres y el agua corran, paralelamente, juntos cuesta abajo (los hombres como metáforas del agua), y, por el otro, en que los hombres compitan con otros faenantes por llegar primeros al lugar donde las familias estaban esperando para recibirlos (el descenso más rápido como reconocimiento social de la culminación de una ardua pero óptima labor agrícola); entonces, ese uso del celular iba a atentar contra la eficacia simbólica del ritual. Por eso, la petición del joven faenante fue colectivamente negada. Y, luego de ello, se dispusieron a «hacer cumplir la tradición». Es esta escena en torno al agua la que demuestra una colectiva resistencia hacia un uso del celular que atentaba con romper la continuidad del uso de símbolos rituales anclados como ancestrales, sobre todo para los comuneros más viejos. Después de todo, «(...) lo importante de la continuidad es el reclamo que los agentes hacen sobre su historia para que esta responda a su sentido de tradición, pertenencia y autenticidad» (Borea, 2008: 98).

\section{III.3.2. Las nuevas TIC y la continuidad de la tradición}

Y es que cuando el celular, en el Yarqa Aspiy, no atentaba contra lo que ellos entienden como tradición, se dejaba que esta nueva TIC ingrese, ya no como elemento amenazador, sino como herramienta que, como ya hemos visto, resultaba útil para preservar tradiciones culturales, registrar prestigio social y construir evidencias político-legales que iban año tras año actualizándose. Estos procesos no son arbitrarios en Yanque, pues la comunidad, de manera activa y consciente, decide qué usos son permitidos y qué otros son rechazados. Recordemos que antes había dos discotecas cerca de la plaza de Yanque pero fueron clausuradas porque en una reunión de junta comunal se acordó que ambas «rompían con la tradición». ¿Por qué este elemento fue rechazado en Yanque y por qué otros elementos, como la televisión, la fotocopiadora, la computadora, el Internet o el celular, han sido aceptados? Porque este elemento, a diferencia de los demás, iba a atentar directamente con la construcción de un paisaje rural que, en oposición a Chivay, se vende como «tradicional», pues esa representación de la tradición le es funcional, económicamente hablando, a varios yanqueños cuyas actividades, como el turismo o la artesanía, dependen de la misma. Nos podemos dar cuenta, entonces, a partir de ambos casos -el descenso desde el Mismi y la discoteca en la plaza del pueblo- que los intereses políticos y religiosos particulares de los yanqueños es lo que determina qué es tradición y qué elementos de la modernidad son permitidos en la comunidad y en qué contextos pueden ser usados, evidenciando la maleabilidad de los yanqueños para recoger y adaptar elementos foráneos (las nuevas TIC) al contexto local (político y religioso) con el objetivo de perpetuar sus tradiciones a través de medios no tradicionales.

\section{Conclusión: balances, comparaciones y aporte}

Se vuelve rescatable la maleabilidad de los yanqueños para recoger y adaptar elementos foráneos (las nuevas TIC) al contexto local (político y religioso) con el objetivo de perpetuar sus tradiciones a través de medios no tradicionales. Hemos encontrado, en primer lugar, que la acción de grabar no significa solamente un acto de preservación cultural, sino también un registro del prestigio social, allí donde el foco de lo audiovisual se concentraba durante las ceremonias festivas y rituales en los pasantes de un cargo local (el Yaku Alcalde y los alferados devotos). En segundo lugar, hemos encontrado que la Municipalidad Distrital de Yanque utiliza lo audiovisual para registrar las labores comunales (como limpieza de acequias) a donde se envía peones en representación del Alcalde, teniendo, así, una evidencia política tanto de interés como de compromiso por los asuntos del pueblo. Asimismo, hemos ubicado que el Presidente de la Comunidad utiliza lo audiovisual para registrar las labores de escarbos de canales de riego y los rituales en torno al Tata Mallku y la Mama Pacha, teniendo, así, una evidencia legal del constante mantenimiento de 
la infraestructura hidráulica, material que refuerza, a la par con ciertos mitos locales, su derecho de acceso y usufructo de las aguas de los nevados que se encuentran fuera de su jurisprudencia territorial. Y, en tercer lugar, hemos encontrado que existe una colectiva resistencia al uso del Internet y el celular cuando estos atentan con romper la continuidad de las costumbres y el uso de símbolos rituales.

Por otro lado, los usos políticos y religiosos de las nuevas TIC en las fiestas y en los rituales de la comunidad de Yanque encuentran muy poco eco en otros estudios ya revisados, y que se centran exclusivamente en la documentación y revitalización de lo local; es decir, en la preservación cultural (Huber, 2000; Quinteros, 2011; Van Der Zalm, 2011; Underberg y Zorn, 2013; Castro, 2016). Pero los usos económicos, políticos y religiosos de las nuevas TIC en los Andes peruanos no constituyen un caso aislado. Si bien es cierto que los estudios científico-sociales concernientes a los usos indígenas del Internet y el celular son relativamente nuevos (Dyson, Grant y Hendriks, 2016), las nuevas TIC son usadas por muchas sociedades rurales alrededor del mundo; incluso en las tribus indígenas de Australia, allí donde Bronislaw Malinowski sentó las bases etnográficas para el trabajo de campo antropológico, lo digital ha llegado a constituir un elemento importante en la vida cotidiana de la gente local, poniendo en evidencia que la dimensión socio-cultural es determinante: entre los Koorie (Huebner, 2013), los Anangu (Scales et al., 2013), los Wujal Wujal (Dyson y Brady, 2013), los Ngaanyatjarra (Featherstone, 2013), se graban historias de corte personal y comunal para recuperar y preservar el conocimiento, la memoria y la identidad; entre los Wadawurrung (Chester, 2013), el video es utilizado para documentar lugares significantes dentro de sus territorios tradicionales para ser utilizado en la negociación de los derechos de tierras y en la resistencia ante proyectos de desarrollo no deseados; en otras zonas de Australia, las nuevas TIC sirven para propósitos de conservación cultural de las comunidades indígenas (Van Der Meer et al., 2015); y, en una comunidad de Papúa Nueva Guinea, convive la tradición con la modernidad, pues los celulares no han reemplazado los canales de comunicación tribales: a la par que el celular sirve para la comunicación privada, los tambores de madera locales (encarnando poderosos espíritus vinculados a los líderes de influencia en la comunidad) sirven para la comunicación pública (Watson y Duffield, 2016).

Asimismo, las nuevas TIC son usadas para la preservación cultural no solo en los Andes o en Australia. Este uso, de hecho, es bastante común alrededor de las sociedades rurales del mundo. Schein (2002) sostiene que la producción mediática de la comunidad de migrantes chinos Hmong en Norteamérica es una fuerza mayor dentro de la vida social en términos de formación de identidad, pues, siendo una minoría étnica en Estados Unidos, los Hmong negocian sus prácticas culturales produciendo determinadas narrativas para enunciar sus propias memorias, genealogías de guerra, sentimientos de pérdida y luchas de reasentamiento dentro de contextos sociales mediáticos dominantes. Ginsburg (2002) apunta que los indígenas Inuit están utilizando los medios para resignificar sus tradiciones, para recuperar su propia historia e historias colectivas que han sido borradas de las narrativas nacionales de la cultura dominante y que también están en peligro de ser olvidadas dentro de su mundo local; por ello, los medios son utilizados como tecnologías de representación que juegan un rol revitalizador en la preservación cultural y en la producción de una forma de movilización política; y Leuthold (1998), al estudiar la estética indígena, halló que las tecnologías visuales eran utilizadas como medios de representación de la identidad colectiva de los nativos norteamericanos.

Pero nuestros hallazgos no tienen que ver solamente con dichos usos agrícolas y turísticos (sobre los cuales, además, hay una considerable cantidad de bibliografía fuera del mundo andino); ni siquiera tienen que ver únicamente con dichos usos festivos y rituales (sobre los 
cuales, ciertamente, hay poca bibliografía en general). Consideramos que nuestro aporte a la literatura antropológica andina yace en poner en evidencia la función dilemática de las nuevas TIC: por un lado, preserva la cultura local; por el otro, preserva la jerarquía social. Salvaguarda la cultura yanqueña, con todo lo que ella contiene. Esto es algo de lo cual poco o nada se ha investigado desde los Estudios Andinos, e incluso, aunque con algunas excepciones, desde la Antropología Digital, como el estudio de Williams (2012), que ha puntualizado que las nuevas TIC representan aspectos importantes para el proceso de legitimación de las jerarquías sociales en tribus africanas de hoy; o el estudio de Turner (2002), que ha señalado que los Kayapo del Brasil Central, usan la imagen audiovisual como un documento para reimaginar las identidades sociales de los indígenas en contextos de interacción con el Estado, sistemas globales y otros agentes exógenos.

Decir que las nuevas TIC son usadas para preservar la cultura es mostrar el rostro más hermoso de un proceso de perpetuación global de lo que ya existe localmente: la lengua, la gastronomía, los trajes, los bailes, la música, los sitios arqueológicos, los mitos y ritos, las costumbres y tradiciones. La otra cara de este proceso es que no solamente se preservan objetos y prácticas culturales, sino también jerarquías sociales. De este modo, las nuevas TIC también sirven para reproducir las inequidades sociales, el poder de las autoridades locales y el de las familias privilegiadas de Yanque. Ciertamente, las nuevas TIC, lejos de desintegrar la cultura, son un medio para reafirmarla, pero para reforzar también la estructura social. Desde ese punto de vista, creemos que argumentar que el objetivo de las nuevas TIC es el de preservar la cultura local es -como diría Geertz (1989)- una descripción superficial; mientras que señalar que el sentido profundo se halla, en buena medida, en el registro del prestigio social, en la lucha de intereses políticos y religiosos, es una descripción densa. Vistas así las cosas, no es raro que quienes más se oponen a la supuesta desaparición de mitos y rituales sean los que han pasado (adultos mayores) o van a pasar (adultos) cargos políticos y religiosos, invocando, explícitamente, a la necesidad de proteger las tradiciones y costumbres locales: existe, pues, una preocupación por preservar la cultura local. Pero, a un nivel mucho menos evidente, podemos darnos cuenta de que si desaparecen los rituales y mitos, desaparecen también los cargos políticos y religiosos que permiten su producción y reproducción, y, con ellos, desaparece, asimismo, la posibilidad de obtener prestigio social a través de una dimensión que no sea la económica.

Excepcionalmente, -y a diferencia de lo que sí ocurre con la actividad turística- no son sólo las familias campesinas que más dinero tienen las que logran insertarse en una actividad agrícola mejor coordinada con las nuevas TIC. Creemos que tal vez, en este escenario social, las unidades domésticas más pobres no encuentran mayores problemas para usar el celular en la agricultura porque el capital económico que se requiere para acceder a esta nueva TIC no es alto y se invierte solo una vez, sin considerar, claro está, las recargas periódicas de saldo para activar los celulares. Pero además, en términos de capacitación técnica, la organización de la producción y la comercialización de la agricultura a través del celular solamente requiere los mínimos conocimientos digitales, como el saber marcar y contestar las llamadas telefónicas.

Así, pues, las nuevas TIC sirven para que quienes dominan reafirmen su poder político y religioso y su posición privilegiada dentro del campo social estratificado de la comunidad; sirven también para que quienes tienen mayor poder económico (los dueños de los hoteles sobre los comuneros de las casas vivenciales, y estos últimos sobre los comuneros que no tienen suficiente capital económico para insertarse en la actividad turística) obtengan mayores ingresos. No es casualidad que las familias que tienen más topos de tierra o cabezas de ganado (las familias pudientes, desde la dimensión económica), sean las mismas que tienen acumulado prestigio 
social por haber pasado o pasar cargos políticos y religiosos dentro de la comunidad. Ni es casualidad que la actividad turística en Yanque genere efectos bastantes limitados en el desarrollo local, pues, aunque mejora la infraestructura de los servicios en la comunidad, los ingresos se distribuyen solo entre las familias que logran insertarse en esta actividad. Y solo las familias que más capital detentan -económico y/o político- pueden diversificar sus actividades productivas e insertarse de mejor manera en el turismo, habiendo familias que, a partir del nacimiento del turismo como actividad económica en Yanque, se han posicionado mejor que otras.

Y he ahí justamente el dilema de los usos económicos, políticos y religiosos de las nuevas TIC en la comunidad de Yanque en el Valle del Colca (Caylloma, Arequipa). Por un lado, el Internet y el celular sirven para salvaguardar la cultura local de la comunidad, permitiendo la revitalización de la lengua, la gastronomía, los trajes, los bailes, la música, los sitios arqueológicos, los mitos y ritos, las costumbres y tradiciones dentro de un escenario local-nacional-global del siglo XXI. Por otro lado, los motivos de dicha apuesta revitalizadora de la cultura yanqueña no son gratuitos, pues esta les sirve a las familias de poder para adaptarse al mercado global del turismo y a las autoridades locales para conservar-acceder al prestigio social de los cargos políticos y religiosos. Y si en buena medida, hay cargos que son impuestos (y no elegidos voluntariamente), no son impuestos a cualquiera: es una obligación moral para los que más han acumulado o heredado solamente, pero una obligación que deviene luego en notoriedad social. Y es que no cualquiera puede tener el prestigio social que produce un estatus dominante, porque no cualquiera puede acceder a ser alferado o devoto de una fiesta, participantes del turismo rural comunitario o a la presidencia de la Comisión de Turismo (solo los que más dinero tienen); no cualquiera puede acceder a ser Yaku alcalde o a la presidencia de la Comisión de regantes (solo los que más tierras tienen); no cualquiera puede acceder a ser Rikuy, Kamachikusqa o Kamachikuq Yana (solo los que tienen más conocimientos religiosos heredados de sus padres o abuelos). En ese contexto, los que más tienen (dinero, tierras, conocimientos) usan las nuevas TIC para reforzar su notoriedad social, reproduciendo, así, como también señala Kvasny (2006), las inequidades económicas, políticas y religiosas existentes en el pueblo.

\section{Bibliografía}

Abu-Lughod, L. (2012). Escribir contra la cultura. En Andamios. Revista de Investigación Social, 09(19): 129-157.

Appadurai, A. (1996). Modernity at Large. Cultural Dimensions of Globalization. Minneapolis: University of Minnesota Press.

Arguedas, J. M. (1985). Indios, mestizos y señores. Lima: Horizonte.

Autoridad Nacional del Agua (ANA) (2014). Cuadro de Valores de Retribución Económica. Tarifa por Uso de Infraestructura Hidráulica Menor de la Junta de Usuarios del Valle del Colca, Resolución Administrativa ${ }^{\circ}$ 006-2013-ANA/ALA.CSCH.

Barrionuevo, A. (1971). El Varayoq. Equilibrador entre dos mundos. Lima: CIBA.

Benavides, M. (1987). Apuntes históricos y etnográficos del valle del río Colca (Arequipa, Perú), 1575-1980. En Boletín de Lima, 50: 07-20.

Benavides, M. (1988). La división social y geográfica Hanansaya / Urinsaya en los pueblos del Colca y la provincia de Caylloma (Arequipa, Perú). En Boletín de Lima, 60: 49-53.

Benavides, M. (1998). Las batallas de Chachayllo: la lucha por el agua en riego en el valle del Colca (Arequipa, Perú). En Espacio y Desarrollo, 10: 75-93.

Benavides, M. y H. Llosa (1994). Arquitectura y vivienda campesina en tres pueblos andinos: Yanque, Lari y Coporaque en el valle del río Colca, Arequipa, Bulletin IFEA, 23(1): 105-150. 
Fiestas, Rituales y Nuevas tic. Usos Políticos y Religiosos del Internet y el Celular en la Comunidad de Yanque (Caylloma, Arequipa)

Bernal, A. (1983). Danzas de la etnia collaguas y colonias: un estudio en la cuenca del Colca, Caylloma. Tesis, Universidad Mayor de San Agustín, Arequipa.

Castro, R (2016). Cuentos de la Cripta: filmes de horror y crisis social en los Andes. En Revista Chilena de Antropología Visual, 27: 01-22.

Chester, S. (2013). Preserving Australia’s Cultural Heritage. En Position, 64: 38-41.

Comaroff, J. y J. Comaroff (1993). Modernity and its Malcontents: Ritual and Power in Post-Colonial Africa. Chicago: University of Chicago Press.

Damonte, G. (2000). Apuntes sobre el teniente gobernador. En Ansión, J.; Diez, Hurtada; y Mujica, L. (eds.). Autoridades en espacios locales: una mirada desde la antropología (pp. 09-124). Lima: PUCP.

De la Cadena, M. (1989). Cooperación y conflicto. En Mayer, E. y De la Cadena, M. Cooperación y conflicto en la comunidad andina. Zonas de producción y organización social (pp. 75-115). Lima: IEP.

Diez Hurtado, A. (2001a). Cambia lo superficial... ¿cambia también lo profundo? La fiesta de la Virgen de las Mercedes en Sechura, Piura. En Cánepa Koch, G. (ed.). Identidades representadas: performance, experiencia y memoria en los Andes (pp. 368-397). Lima: PUCP.

Diez Hurtado, A. (2001b). Organizaciones e integración en el campo peruano después de las políticas neoliberales. En Giarracca, N. (ed.). ¿Una nueva ruralidad en América Latina? (pp. 191-219). Buenos Aires: CLACSO.

Diez Hurtado, A. (2005). Los sistemas de cargos religiosos y sus transformaciones. En Marzal, M. (ed.), Religiones campesinas (pp. 253-286). Madrid: Trotta.

Dyson, L. y Brady, F. (2013). A study of mobile technology in a Cape York community: Its reality today and potential for the future. En Ormond-Parker, L. et al. (eds.). Information Technology and Indigenous Communities (pp. 09-26). Australia: AIATSIS Research Publications.

Dyson, L.; Hendriks, M. y Grant, S. (eds.) (2016). Indigenous People and Mobile Technologies. New York: Routledge.

Featherstone, D. (2013). The Aboriginal invention of broadband: How Yarnangu are using ICTs in the Ngaanyatjarra Lands of Western Australia. En Ormond-Parker, L. et al. (eds.). Information Technology and Indigenous Communities (pp. 27-52). Australia: AIATSIS Research Publications.

Figueroa, A. (1983). La economía campesina de la sierra del Perú. Lima: PUCP.

Fonseca, C. y Mayer, E. (1988). Comunidad y producción en la agricultura andina. Lima: Fomciencias.

Geertz, C. (1989). La interpretación de la cultura. Barcelona: Gedisa.

Gelles, P. (2002). Agua y poder en la sierra peruana: la historia y política cultural del riego, rito y desarrollo. Lima: PUCP.

Ginsburg, F. (2002). Screen Memories: Resignifying the Traditional in Indigenous Media. En Ginsburg, F.; AbuLughod, L. y Larkin, B. (eds). Media Worlds. Anthropology on New Terrain (pp. 39-57). Berkeley: University of California.

Golte, J. (1987). La racionalidad de la organización andina. Lima: IEP.

Gonzales Aguilar, M. (2016). Políticas hídricas y derechos de agua: cambios y continuidades en la organización social del riego en la comunidad de Yanque. Tesis de licenciatura. Lima: PUCP.

Gonzales de Olarte, E. (1982). Economías regionales del Perú. Lima: IEP.

Gonzales de Olarte, Efraín et. al. (ed.). (1987). La lenta modernización de la economía campesina. Diversidad, cambio técnico y crédito en la agricultura andina. Lima: IEP.

Guillet, D. (1978). The Supra-Household Sphere of Production in the Andean Peasant Economy. En XLII Congrès International des Américanistes, París.

Huber, L. (2000). Consumo, cultura e identidad en el mundo globalizado: estudios de caso en los Andes. Lima: IEP.

Huebner, S. (2013). A digital community project for the recuperation, activation and emergence of Victorian Koorie knowledge, culture and identity. En Ormond-Parker, L. et al. (eds.). Information Technology and Indigenous Communities (pp. 171-183). Australia: AIATSIS Research Publications. 
Kervyn, B. (1989). Campesinos y acción colectiva. La utilización del espacio en comunidades de la sierra del Perú. En Revista Andina, 7(1): 07-83.

Kvasny, L. (2006). Social Reproduction and its Applicability for Community Informatics. En The Journal of Community Informatics, 02(2). Documento electrónico. http://ci-journal.net/index.php/ciej/article/ view/342/248, consultado el 14 de octubre de 2017.

Leuthold, S. (1998). Indigenous Aesthetics: Native Art Media and Identity. Austin: University of Texas Press.

Montoya, R. (1979). Producción parcelaria y universo ideológico. El caso de Puquio. Lima: Mosca Azul.

Ossio, Juan (1992). Parentesco, reciprocidad y jerarquía en los Andes. Una aproximación a la organización social de la comunidad de Andamarca. Lima: PUCP.

Plaza, O. y Francke, M. (1981). Formas de dominio, economía y comunidades campesinas. Lima: DESCO.

Quinteros, A. (2011). Entretejidos de imágenes: encuentros, brechas y memorias latentes en el nuevo cine andino. En Cánepa, G. (ed.), Imaginación visual y cultura en el Perú (pp. 413-426). Lima: PUCP.

Ráez, M. (1998). Los ciclos ceremoniales y la percepción del tiempo festivo en el valle del Colca (Arequipa). En Romero, R. (ed.). Música, danzas y máscaras en los Andes (pp.253-297). Lima: PUCP.

Ráez, M. (2001). Jerarquía y autoridad comunal. Los varayos y la Fiesta de Agua de la comunidad campesina de Lachaqui, Canta. En Cánepa Koch, G. (ed.). Identidades representadas. Performance, experiencia y memoria en los Andes (pp.331-368). Lima:PUCP.

Ráez, M. (2002). En los dominios del cóndor. Fiestas y música tradicional del valle del Colca. Lima: PUCP.

Ráez, M. (2008). Celebrando el trabajo. En Romero, R. (ed.). Fiesta en los Andes. Ritos, música y danzas del Perú (pp.102-139). Lima: PUCP.

Ramírez León, L. (2014). La vara de mando popular y tradicional en el Perú. Lima: UNMSM.

Robles Mendoza, R. (2010). Sistemas de riego y ritualidad andina en el valle del Colca. En Revista Española de Antropología Americana, 1(40): 197-217.

Romero, R. (2001). Modernidad, autenticidad y prácticas culturales en la sierra central del Perú. En Cánepa Koch, G. (ed.). Identidades representadas: performance, experiencia y memoria en los Andes (pp. 37-59). Lima: PUCP.

Romero, R. (2004). Identidades múltiples. Memoria, modernidad y cultura popular en el Valle del Mantaro. Lima: Fondo Editorial del Congreso del Perú.

Sánchez Dávila, M. (2016). Nuevas TIC en los Andes peruanos: fundamentos teóricos y balance bibliográfico. En Contratexto, 26: 133-159.

Sánchez Dávila, M. (2017a). Yanque en el valle del Colca (Caylloma, Arequipa). Historia y cultura en los siglos XV-XX. En Haucaypata. Investigaciones arqueológicas del Tahuantinsuyo, 12: 68-78.

Sánchez Dávila, M. (2017b). Comprender la agricultura en los Andes peruanos: economía y política en la comunidad de Yanque (Caylloma, Arequipa). En Revista Antropologías del Sur, 07: 235-256.

Sánchez Dávila, M. (2017c). Comprender la agricultura en los Andes peruanos: religión en la comunidad de Yanque (Caylloma, Arequipa). En Revista Peruana de Antropología, 03: (En prensa).

Scales, S. et al. (2013). The Ara Irititja Proyect: Past, Present, Future. En Ormond-Parker, L. et al. (eds.). Information Technology and Indigenous Communities (pp. 151-169). Australia: AIATSIS Research Publications.

Schein, L. (2002). Mapping Hmong Media in Diasporic Space. En Ginsburg, F.; Abu-Lughod, L. y Larkin, B. (eds.). Media Worlds. Anthropology on New Terrain (pp. 229-244). Berkeley: University of California.

Treacy, J. (1994). Las chacras de Coporaque. Andenería y riego en el Valle del Colca. Lima: IFEA.

Turner, T. (2002). Representation, Politics, and Cultural Imagination in Indigenous Video: General Points and Kayapo Examples. En Ginsburg, F; Abu-Lughod, L. y Larkin, B. (eds.). Media Worlds. Anthropology on New Terrain (pp. 75-89). Berkeley: University of California.

Underberg, N. y Zorn, E. (2013). Digital Ethnography. Anthropology, Narrative and New media. Austin: University of Texas Press. 
Urbano, E. (1991). Modernidad en los Andes. Cusco: Centro Bartolomé de las Casas.

Urbano, E. (1997). Tradición y modernidad en los Andes. Cusco: Centro Bartolomé de las Casas.

Valderrama, R. y Escalante, C. (1988). Del Tata Mallku a la Mama Pacha. Riego, sociedad y ritos en los Andes peruanos. Lima: DESCO.

Valderrama, R. y Escalante, C. (1997). La doncella sacrificada. Mitos del Valle del Colca. Lima: IFEA.

Van der Meer, S. et al. (2015). The Use of ICT to preserve Australian Indigenous Culture and Language - a Preliminarily Proposal Using the Activity Theory Framework. En Indigenous Culture Preservation with ICT, Australasian Conference on Information Systems, Adelaide.

Watson, A. y Duffield, L. (2016). Private Mobile Phones and Public Communication Drums in Rural Papua New Guinea. En Dyson, L.; Hendriks, M. y Grant, S (eds.). Indigenous People and Mobile Technologies (92-106). New York: Routledge.

Williams, C. (2012). Researching Power, Elites and Leadership. London: Sage.

Presentado: 3 setiembre 2017

Aceptado: 23 enero 2018

Publicado online: 11 julio 2018 
